\title{
STRATEGI REKONSTRUKSI EKONOMI PESANTREN MASA DEPAN
}

\author{
Oleh: Adi Ansari*
}

\begin{abstract}
Abstrak
Strategi rekonstruksi ekonomi pesantren adalah rencana yang disatukan, luas, dan terintegrasi yang menghubungkan keunggulan strategi pesantren dengan tantangan lingkungan dan yang dirancang untuk memastikan bahwa tujuan utama pesantren untuk sejahtera secara ekonomi dapat dicapai melalui pelaksanaan yang tepat oleh pesantren. Penulis menyimpulkan ada empat strategi rekonstruksi ekonomi pesantren, yaitu: Strategi pertama adalah analisis potensi ekonomi pesantren. Potensi ekonomi yang dimiliki pesantren adalah: Pertama, kyai-ulama, Kedua, santri dan; Ketiga, pendidikan. Strategi kedua adalah implementasi prosedur anggaran. Kegiatan ini meliputi empat fase kegiatan pokok prosedur penganggaran keuangan, sebagai berikut: 1) perencanaan anggaran; 2) persiapan anggaran; 3) pengelolaan pelaksana anggaran, dan; 4) menilai pelaksanaan anggaran. Strategi ketiga adalah implementasi prinsip manajemen keuangan, Strategi keempat adalah implementasi akuntabilitas dan transfaransi. Akuntabilitas adalah kondisi seseorang yang dinilai oleh orang lain karena kualitas performannya menyelesaikan tujuan yang menjadi tanggung jawabnya.
\end{abstract}

Kata Kunci: rekonstruksi, ekonomi, pesantren

\section{A. Pendahuluan}

Tipe pesantren yang ada di Indonesia ini sangat beragam tapi kalau ditinjau dari kemajuannya, ada pesantren yang memiliki santri kurang dari seribu orang dan ada yang lebih, ada yang berasrama dan ada yang tidak, akan tetapi yang menjadi problema yang sama di antara pesantren-pesantren kecil di Indonesia saat ini adalah ketika kebutuhan akan sarana dan prasarana semakin meningkat sejalan dengan meningkatnya populasi santri. Masalah pendanaan hampir menjadi kendala setiap pergerakan apapun, bagi pesantren masalah ini menjadi permasalahan serius ketika dituntut fasilitas sejalan dengan meningkatnya populasi santri, berbeda dengan sekolah atau perguruan tinggi, masalahnya menjadi lebih kompleks, karena selain mempersiapkan ruangan

* Penulis adalah Dosen Tetap STIT Darul Hijrah Martapura Kalimantan Selatan. 
belajar, sebuah pesantren juga harus mempersiapkan ruang tinggal dan sarananya seperti WC dan kamar mandi dengan ratio minimal 1 berbanding 1020 orang santri.

Jika asrama menampung seratus santri artinya harus tersedia minimal 10 kamar mandi dan WC dengan persediaan air bersih yang cukup, 1 orang 60 liter air per hari, jemuran pakaian dan lain-lain. Lain halnya dengan sekolah atau perguruan tinggi untuk prasarana standar cukup ruang belajar, kantor guru, mushalla dan beberapa buah WC. Permasalahan akan semakin kompleks ketika pesantren memilih pola anak asuh bagi para du'afa dan yatim piatu, karena pendanaan tidak saja dibutuhkan untuk sarana dan prasarana tapi juga untuk konsumsi para santri dan asatidz-nya.

Selain masalah di atas, juga sarana konsumsi seperti dapur dan ruang makan menjadi agenda tambahan, lahan bermain, penghijauan, sarana olah raga, transportasi, sarana kesehatan, ruang inap tamu yang semuanya semakin memperluas medan kebutuhan pesantren sesuai dengan tuntutan zaman dan pola hidup yang berkembang di masyarakat karena berbagai fasilitas tadi menjadi tuntutan baik instansi pemerintahan maupun masyarakat yang akan memesantrenkan anaknya.

Problema di atas kalau dilihat dari akar permasalahannya tidak lain adalah karena lemahnya keuangan pesantren, pesantren tidak mempunyai keuangan yang kuat dan tidak pandai dalam mengelola keuangannya sehingga pembangunan pun terhambat. Kalau seandainya keuangan pesantren diatur dengan profesional maka realitasnya akan berbeda, bahkan kalau seluruh pesantren mempunyai keuangan yang mapan, maka dampaknya juga akan dirasakan oleh masyarakat sekitar, sehingga mampu untuk membuka lapangan kerja dan negara ini pun akan semakin kuat secara keuangan dan terciptalah masyarakat yang sejahtera dan makmur. Oleh karena itu perlu strategi yang efektif dan efesien untuk merekonstruksi ulang ekonomi pada lembaga pesantren di masa depan.

\section{B. Strategi Rekonstruksi Ekonomi Pesantren}

\section{Pengertian Strategi}

Secara historis, kata strategi dipakai untuk istilah dunia militer. Strategi sendiri berasal dari bahasa Yunani "stratogos", yang berarti jendral/komandan militer. Maksudnya adalah strategi berarti seni para jendral, yaitu cara menempatkan pasukan atau menyusun kekuatan tentara di medan perang agar musuh dapat dikalahkan. (Fandy Tjipto, 2008; 3).

Namun, istilah ini tidak hanya digunakan dalam konteks militer saja, bisnis juga menggunakan istilah strategi ini. Dalam konteks bisnis, strategi adalah rencana yang disatukan, luas, dan terintegrasi yang menghubungkan keunggulan strategi perusahaan dengan tantangan lingkungan dan yang dirancang untuk memastikan bahwa tujuan utama perusahaan dapat dicapai 
melalui pelaksanaan yang tepat oleh perusahaan (Lawrence R. Jauch and William Gluech, 1998; 9).

Sedangkan menurut Stoner, Freeman, dan Gilbert Strategi lebih diarahkan pada pengelolaan kegiatan dan operasi suatu bisnis tertentu dan berupaya menentukan pendekatan yang sebaiknya digunakan oleh suatu bisnis terhadap pasarnya dan melaksanakan pendekatan tersebut dengan memanfaatkan sumber daya yang ada dan dalam kondisi pasar tertentu. (Fandy Tjiptono, 1997; 3).

Ansoff mendefinisikan strategi sebagai " $a$ set of decision making rules for guidance of organizational behavior", apabila dikaitkan dengan pemasaran, maka strategi diartikan sebagai pengambilan keputusan mengenai pemakaian faktor-faktor pemasaran yang dapat dikendalikan untuk mencapai tujuan-tujuan yang telah ditentukan (H. Igor Ansoff, 1990; 43). Tujuan utamanya adalah agar perusahaan dapat melihat secara obyektif kondisi-kondisi internal dan eksternal, sehingga perusahaan dapat mengantisipasi perubahan lingkungan eksternal. Dalam hal ini dapat dibedakan secara jelas fungsi manajemen, konsumen, distributor, dan pesaing. Jadi, perencanaan strategis penting untuk memperoleh keunggulan bersaing dan memiliki produk yang sesuai dengan keinginan konsumen dengan dukungan yang optimal dari sumber daya yang ada.

Berdasarkan paparan di atas penulis menyimpulkan bahwa strategi di sini adalah rencana yang disatukan, luas, dan terintegrasi yang menghubungkan keunggulan strategi pesantren dengan tantangan lingkungan dan yang dirancang untuk memastikan bahwa tujuan utama pesantren untuk sejahtera secara ekonomi dapat dicapai melalui pelaksanaan yang tepat oleh pesantren.

\section{Strategi Pertama: Analisis Potensi Ekonomi Pesantren}

Urgensi pengelolaan dan pengembangan mengingat banyaknya potensi ekonomi yang dimiliki oleh pesantren. Potensi ekonomi yang dimiliki pesantren adalah (A. Halim, 2005; 223): Pertama, kyai-ulama, kyai-ulama pesantren yang dipandang sebagai potensi pesantren yang mempunyai nilai ekonomis, setidaknya dapat kita lihat pada tiga hal: 1) kedalaman ilmu kyaiulama. Artinya, figur seorang kyai merupakan magnet (daya tarik) yang luar biasa bagi calon santri untuk berburu ilmu; 2) pada umumnya, seorang kyai adalah tokoh panutan masyarakat dan pemerintah. Ketokohan seorang kyai ini memunculkan sebuah kepercayaan, dan dari kepercayaan melahirkan akses dan; 3) pada umumnya, seorang kyai sebelum membangun pesantren telah mandiri secara ekonomi, misalnya sebagai petani, pedagang, dan sebagainya. Sejak awal kyai telah mempersiapkan diri secara sungguh-sungguh, tidak hanya dari aspek mental, tetapi juga sosial ekonomi. Jiwa dan semangat entrepreneurship inilah yang mendasari kemandirian perekonomian pesantren. Apabila aset dan jiwa entrepreneurship ini dipadukan, maka hasilnya dapat dijadikan dasar membangun tatanan ekonomi pesantren. Kedua, santri, potensi 
ekonomi kedua yang melekat pada pesantren adalah para santri. Hal ini dipahami bahwa pada umumnya santri mempunyai potensi/bakat bawaan seperti kemampuan membaca Al-Qur'an, kaligrafi, pertukangan, dan lain sebagainya. Bakat bawaan ini sudah seharusnya selalu dipupuk dan dikembangkan agar menjadi prokuktif. Ketiga, pendidikan, potensi ekonomi dari pendidikan pesantren ini terletak pada santri/murid, guru, sarana dan prasarana. Dari sisi santri/murid, sudah barang tentu dikenai kewajiban membayar SPP, di samping sumbangan-sumbangan wajib lainnya. Untuk kelancaran proses belajar mengajar, diperlukan seperangkat buku, kitab, dan alat-alat tulis. Dari sini bisa dikembangkan salah satu unit usaha pesantren yang menyediakan sarana belajar tersebut. Misalnya toko buku/kitab, alat tulis, dan photo copy. Belum lagi dari sisi kebutuhan sehari-hari, seperti makan, minum, air, telpon, asrama, pakaian, dan lain sebagainya (A. Halim, 2005; 224).

Melihat begitu banyaknya peluang untuk mengembangkan wirausaha di pesantren, maka akan sangat menguntungkan jika pesantren mengelolanya menjadi kegiatan usaha ekonomi. Kegiatan ini dapat dikembangkan oleh pesantren dan dimulai dengan: 1) perencanaan (menumbuhkan gagasan, menetapkan tujuan, mencari data dan informasi, merumuskan kegiatankegiatan usaha dalam mencapai tujuan sesuai dengan potensi yang ada, melakukan analisis SWOT, dan memusyawarahkan) dan; 2) pemilihan jenis usaha dan macam usaha.

Dalam menentukan kegiatan ini yang perlu diperhatikan adalah: 1) luas lahan yang dimiliki oleh pesantren; 2) sumber daya manusia pesantren; 3) Tersedianya sarana peralatan dan bahan baku yang ada di pesantren dan; 4) kemungkinan pemasarannya. Ini erat kaitannya dengan potensi permintaan masyarakat terhadap jenis produksi, barang atau bahkan jasa tertentu (Tim Penyusun, 2003; 94-95).

Atas dasar beberapa pertimbangan tersebut, maka jenis-jenis usaha yang dapat didirikan di pesantren adalah: 1) bidang perdagangan; 2) bidang pertanian dan agribisnis; 3) bidang industri kecil; 4) bidang elektronika dan perbengkelan; 5) bidang pertukangan kayu; 6) bidang jasa; 7) bidang keuangan/lembaga keuangan; 8) bidang koperasi dan; 9) bidang pengembangan teknologi tepat guna. Berbagai bidang wirausaha yang sangat strategis di atas telah dikembangkan dan dikelola di berbagai pesantren. Dengan pengelolaan dan pengembangan wirausaha banyak manfaat yang diperoleh, di antaranya membantu pendanaan pesantren, memberdayakan ekonomi masyarakat, dan pendidikan kewirausahaan bagi para santrinya.

\section{Strategi Kedua: Implementasi Prosedur Anggaran}

Prosedur anggaran merupakan suatu langkah perencanaan yang fundamental, jadi anggaran atau budget adalah sebagai suatu rencana operasi dari suatu kegiatan atau proyek yang mengandung perincian pengeluaran biaya 
untuk periode tertentu dan dalam jangka waktu tertentu. Adapun fungsi penganggaran adalah proyeksi kegiatan finansial yang diperlukan guna mencapai tujuan yang akan dilaksanakan oleh suatu organisasi (perusahaan, yayasan, atau pondok pesantren).

Untuk penyusunan anggaran secara umum dalam lembaga pendidikan perlu dikembangkan dalam format-format yang meliputi: sumber pendapatan, pengeluaran untuk kegiatan belajar mengajar, pengadaan dan pemeliharaan sarana prasarana, bahan-bahan dan alat pelajaran, honorarium dan kesejahteraan.

Kegiatan di atas meliputi empat fase kegiatan pokok prosedur penganggaran keuangan, sebagai berikut: 1) perencanaan anggaran, merupakan kegiatan mengidentifikasi tujuan, menentukan prioritas, menjabarkan tujuan ke dalam operasional yang terukur, serta adanya analisis yang terarah dalam pencapaian tujuan, serta membuat rekomendasi alternatif untuk mencapai sasaran; 2) persiapan anggaran, yaitu adanya kesesuaian anggaran yang telah ada dengan segala bentuk kegiatan, baik pendistribusian, program pengajaran yang akan dicanangkan serta adanya inventarisasi kelengkapan peralatan dan bahan-bahan yang tersedia; 3) pengelolaan pelaksana anggaran, prosedur yang harus di terapkan dalam pelaksana anggaran adalah, adanya pembukuan yang jelas dan teratur, pembelanjaan dan transaksi yang sesuai dengan ketentuan-ketentuan yang telah ada. Perhitungan yang jelas dan terencana, pengawasan prosedur kerja sesuai dengan ketentuan yang berlaku, melakukan serta membuat laporan keuangan sebagai bentuk pertanggungjawaban keuangan terhadap lembaga dan; 4) menilai pelaksanaan anggaran, dari semua anggaran yang telah dibuat dan diaplikasikan ke taraf pendidikan praktis, perlu adanya evaluasi sebagai rekomendasi untuk perbaikan manajemen dan anggaran yang akan datang.

Satu hal yang perlu diperhatikan dalam penganggaran keuangan adalah menerapkan prinsip anggaran berimbang, artinya antara pendapatan dan pengeluaran harus berimbang dan diupayakan tidak terjadi anggaran pendapatan minus (M. Sulthon Masyhud dan M. Khusnurdilo, t.t: 189).

\section{Strategi Ketiga: Implementasi Prinsip Manajemen keuangan}

Pertama, Prinsip Perencanaan. Sumber dana pesantren tidak hanya diperoleh dari SPP saja, tetapi bisa juga menggali dari sumber lain misalnya lembaga wakaf pesantren. Untuk itu di pesantren sebenarnya juga perlu dibentuk organisasi orang tua santri yang implementasinya dilakukan dengan membentuk komite atau majelis. Komite atau majelis tersebut beranggotakan wakil wali santri, tokoh masyarakat, pengelola, wakil pemerintah dan wakil ilmuwan/ulama di luar lembaga dan dapat juga memasukkan kalangan dunia usaha dan industri. Selanjutnya pihak pesantren bersama komite atau majelis pada setiap awal tahun anggaran perlu bersama-sama merumuskan Rencana Anggaran Pendapatan dan Belanja Pondok Pesantren (RAPBPP) sebagai acuan 
bagi pengelola dalam melaksanakan manajemen keuangan yang baik.

Jika dalam suatu lembaga pendidikan Islam RAPBPP disusun oleh kepala sekolah/madrasah, maka kepala sekolah/madrasah harus mampu dalam menyusun dan mengetahui sumber-sumber dana yang merupakan sumber daya sekolah (Sulistyorini, t.t; 132). Ada dua bagian pokok anggaran yang harus diperhatikan dalam penyusunan RAPBS, yaitu: 1) Rencana sumber atau target penerimaan/ pendapatan dalam satu tahun yang bersangkutan, termasuk di dalamnya keuangan bersumber dari: a) kontribusi siswa; b) sumbangan dari individu atau organisasi; c) sumbangan dari pemerintah; d) dari hasil usaha. 2) Rencana penggunaan keuangan dalam satu tahun yang bersangkutan, semua penggunaan keuangan lembaga dalam satu tahun anggaran perlu direncanakan dengan baik agar kehidupan lembaga dapat berjalan dengan baik. Setelah mengetahui dan memahami bagian-bagian pokok yang ada dalam penyusunan RAPBS serta sumber dana yang ada selanjutnya kepala sekolah/madrasah menyusun RAPBS dengan membentuk tim penyusun dari dewan guru. Dalam menetapkan jumlah anggaran ada dua hal yang perlu diperhatikan yaitu: satuan biaya dan volume biaya.

Kedua, Prinsip Pelaksanaan. Setelah dana didapatkan melalui perencanaan yang baik, maka manajer lembaga pendidikan Islam harus berusaha mengembangkannya melalui usaha-usaha produktif agar uang tidak mandeg atau habis (Mujamil, t.t; 168). Hal tersebut dilakukan dengan penuh pertimbangan dan kehati-hatian dan tentunya harus berbagi dengan alokasi dana yang akan dipakai untuk operasional atau keberlangsungan lembaga dan pengadaan saran pra sarana lembaga. Kepala sekolah sebagai manajer berfungsi sebagai penentu yang berhak untuk memerintahkan pembayaran.

Bendaharawan (pejabat yang berwenang melakukan penerimaan penyimpanan dan pengeluaran uang dan surat berharga lainnya serta wajib membuat perhitungan dan pertanggungjawaban) sekolah Islam dalam mengelola keuangan sekolah hendaknya memperhatikan beberapa hal: 1) Hemat dan sesuai dengan kebutuhan; 2) Terarah dan terkendali sesuai dengan rencana dan; 3) Tidak diperkenankan untuk kebutuhan yang tidak menunjang proses belajar mengajar, seperti ucapan selamat, hadiah, dan pesta (Sulistyorini, t.t; 135).

Hal itu kiranya dalam pelaksanaan pengelolaan keuangan pada lembaga pendidikan Islam dapat berjalan efektif dan tepat sasaran. Sehingga mengurangi kemungkinan akan terjadi pemakaian dana yang tidak efektif atau mubazir. Pada hal yang sama kaitannya tentang pelaksanaan kelola keuangan, ada kiat-kiat agar sang pemberi dana kepada suatu lembaga menjadi percaya terhadap suatu lembaga pendidikan Islam. Pihak sekolah wajib menjaga kepercayaan itu, yaitu di antara yang dirumuskan adalah: 1) Penggunaan anggaran harus benar-benar sesuai dengan program yang direncanakan; 2) Anggaran harus digunakan seefisien mungkin; 3) Hindari kesan bahwa pemakaian dana sekedar menghabiskan anggaran saja dan; 4) Pengeluaran dananya dilakukan oleh petugas yang berwenang. (Mujamil, t.t: 169). 
Dengan demikian diharapkan pelaksanaan kelola keuangan di lembaga pendidikan Islam berjalan dengan bersih dan professional, sehingga para donator pun akan terjaga kepercayaannya dan pada tahap berikutnya bersedia memberikan dana lagi. Perumusan beberapa poin di atas sangat beralasan ketika kita melihat bagaimana tata kelola keuangan yang terjadi di sebagian besar lembaga pendidikan Islam yang asal-asalan dan jauh dari profesionalitas. Baik itu karena kurangnya SDM dalam mengelola maupun tak adanya kejujuran di kalangan pengelola sendiri.

Ketiga, Prinsip Pelaporan dan Pengawasan. Semua pengeluaran keuangan di lembaga pendidikan Islam dari sumber manapun harus dipertanggungjawabkan, hal tersebut merupakan bentuk transparansi dalam pengelolaan keuangan. Namun demikian prinsip transparansi dan kejujuran dalam pertanggungjawaban tersebut harus tetap dijunjung tinggi. Dalam kaitan dengan pengelolaan keuangan tersebut, yang perlu diperhatikan oleh bendaharawan adalah: 1) Pada setiap akhir tahun anggaran, bendahara harus membuat laporan keuangan kepada komite/kamad untuk dicocokkan dengan RAPBS/RAPBPP; 2) Laporan keuangan tersebut harus dilampiri bukti-bukti pengeluaran yang ada; 3) Kwitansi atau bukti-bukti pembelian atau bukti penerimaan dan bukti pengeluaran lain dan; 4) Neraca keuangan juga harus ditunjukkan untuk diperiksa oleh tim pertanggungjawaban keuangan dari komite sekolah dan kamad.

Selain buku neraca keuangan yang erat hubungannya dengan pengelolaan keuangan, ada juga beberapa buku lain yang penting bagi bendaharawan sebuah lembaga pendidikan Islam yaitu: 1) Buku kas umum; 2) Buku persekot uang muka; 3) Daftar potongan-potongan; 4) Daftar gaji/ honorarium; 5) Buku tabungan; 6) Buku iuran/kontribusi siswa (SPP/infaq) dan; 7) Buku catatan lain-lain yang tidak termasuk di atas, seperti catatan pengeluaran insidentil.

Buku-buku tersebut perlu diadakan, agar manajemen keuangan di suatu lembaga pendidikan Islam dapat berjalan dengan baik, transparan, memudahkan dilakukan pengawasan terhadap penggunaan anggaran yang ditetapkan, serta tidak menimbulkan kecurigaan atau fitnah. KH. Imam Zarkasyi Pendiri Pondok Modern Gontor mengatakan " administrasi yang baik adalah cara yang tepat untuk menjaga kepercayaan" (Abdullah Syukri, 2005). hal itulah kiranya yang menjadikan pesantren Gontor tertib secara administrasi dalam setiap komponennya, sehingga dapat mapan secara finansial.

Pengawasan juga bisa disebut control manajerial adalah merupakan salah satu fungsi manajemen dalam organisasi (Sulistyorini, t.t; 136). Fungsi tersebut mutlak dilakukan pada setiap kesatuan lembaga pendidikan Islam. Karena jika tidak maka akan sangat mempengaruhi pencapaian tujuan pendidikan di suatu lembaga tersebut. Pelaksanaan pengelolaan keuangan di suatu lembaga pendidikan Islam harus selalu diawasi oleh kepala sekolah atau pimpinan selaku manajer dalam lembaga tersebut. Hal itu dimaksudkan tidak akan terjadinya tindakan penyelewengan dalam penggunaan dana yang ada. 
Dalam melakukan pengawasan ada beberapa butir pertanyaan yang dapat diajukan: 1) Apakah laporan keuangan disusun menurut ketentuan yang berlaku? 2) Apakah laporan keuangan disusun secara konsisten dari waktu ke waktu? 3) Apakah penjelasan dalam laporan keuangan diberikan secara memadai?

Dengan beberapa pertanyaan tersebut bagaimana hendaknya dijawab "ya" oleh setiap lembaga. Karena hal itu berarti sebuah lembaga telah menjalankan tugasnya dengan baik guna menjaga kepercayaan pemerintah dan masyarakat yang telah mendonasikan sejumlah dana.

\section{Strategi Keempat: Implementasi Akuntabilitas Keuangan Pesantren}

Ketika sebuah pesantren sudah mapan secara ekonomi, biasanya banyak permasalahan yang akan dihadapi, bahkan mungkin lebih berat bila dibandingkan dengan ketika pesantren tersebut mulai dirintis, karena biasanya yang menjadi sumber permasalahan adalah orang-orang yang berjasa dan berjuang diawal pendirian pesantren tersebut biasanya karena adanya benturan kepentingan, terutama karena masalah keuangan. Oleh karena itu perlu sebuah akuntabilitas keuangan dan transfaransi sistem yang baik sehingga kesatuan hati di antara pengurus pesantren tidak pecah bahkan saling bahu-membahu untuk mengembangkan sayap ekonomi pesantren menuju ekonomi pesantren yang semakin kuat oleh karena itu akuntabilitas dan transparansi sistem keuangan pesantren merupakan komponen yang paling penting.

Pidarta menguraikan bahwa akuntabilitas adalah kondisi seseorang yang dinilai oleh orang lain karena kualitas performannya menyelesaikan tujuan yang menjadi tanggung jawabnya. Sedangkan Elliot mengatakan bahwa akuntabilitas adalah: 1) cocok atau sesuai (fitting in) dengan peranan yang diharapkan oleh orang lain; 2) menjelaskan dan mempertimbangkan kepada orang lain tentang keputusan dan tindakan yang diambilnya dan; 3) performen yang cocok dan meminta pertimbangan orang lain (Made Pidarta, t.t; 156-157).

Lebih lanjut, Pidarta menegaskan bahwa dalam indikator akuntabilitas pendidikan terdapat beberapa elemen, yakni rasa puas dari pihak-pihak yang menaruh perhatian kepada pendidikan, model kontrak/kontrol, model dialog, dan kriteria/ukuran. Rasa puas itu sendiri berasal dari kenyataan bahwa para petugas pendidikan mampu memenuhi kontrak mereka sebagai hasil dialog sebelumnya, yaitu tepat dengan kriteria yang sudah ditentukan yang tercermin dalam kontrol yang dilakukan oleh pihak-pihak lain tersebut.

Akuntabilitas dalam mengembangkan dana pondok pesantren di mulai

dari perencanaan, pengumpulan, pengelolaan, pemanfaatan, dan pertanggungjawaban. Akuntabilitas akan dipengaruhi oleh performen para perencana dan para petugas lainnya, dalam hal ini kyai dan para pembantunya atau unsur pimpinan dalam pesantren yang menerapkan kepemimpinan kolektif. Lebih lanjut Wahid menguraikan bahwa pola kepemimpinan pesantren yang menerapkan sistem kepemimpinan kolektif secara tidak 
langsung berimbas pada pertanggungjawaban pengelolaan dana disampaikan dalam rapat pengurus terlebih dahulu, selanjutnya disampaikan kepada publik (Wahid Zaini, 1999; 45).

Langkah-langkah yang dilakukan pengelola pondok pesantren dalam melakukan akuntabilitas melalui tahapan-tahapan sebagai berikut: 1) Pra pelaksanaan akuntabilitas atau proses pengembangan dana pondok pesantren hal ini dilakukan dengan cara membentuk dua lembaga yaitu pertama Badan Usaha Milik Pesantren (BUMP) yang bertanggung jawab terhadap pengembangan dana pondok pesantren, kedua Badan Pengawas Keuangan Dan Kekayaan Ma'had (BPK2M) yang bertugas mengawasi kekayaan, aset dan keuangan pondok pesantren; 2) Pelaksanaan akuntabilitas dengan melalui pengurus harian dengan melakukan evaluasi setiap empat bulan sekali yang dipimpin langsung oleh pengasuh dan yang paling penting adalah; 3) merekrut pegawai akuntan yang profesional yang jujur.

Akuntansi keuangan adalah suatu sistem yang terdiri dari metode dan catatan-catatan yang dibuat untuk mengidentifikasikan, mengumpulkan, menganalisis, mencatat dan melaporkan keuangan-keuangan organisasi dan menyelenggarakan pertanggungjawaban (Goerge H. Bodnar dan William S. Hopwood, 2001; 181-182). Sebuah organisasi tentunya membutuhkan pengelola keuangan untuk memastikan tertopangnya kegiatan operasional dari aspek pendanaan, Tidak terkecuali pesantren. Akuntansi adalah pembukuan, pengaturan atau pengurusan (Pius A Partanto dan M. Dahlan al-Barry, 1994; 6). Di setiap pesantren memerlukan dana yang cukup untuk menjalankan sejumlah program kegiatan dalam periode tertentu. Seperti halnya organisasiorganisasi umum lainnya, dana yang dimiliki pesantren harus diatur dan dicatat sedemikian rupa agar jelas arus masuk dan keluarnya, termasuk ketepatan penggunaannya. Pencatatan dan pengelolaan dana yang baik menjadi kegiatan yang penting sebagai wujud pertanggungjawaban pesantren. Pada dasarnya pelaksanaan akuntansi keuangan hanya meliputi penerimaan atau pemasukan dan pengeluaran.

Dalam melakukan akuntansi keuangan, kita perlu menegakkan prinsipprinsip keadilan, efisiensi, transparansi, dan akuntabilitas publik. Selanjutnya pembahasan mengenai akuntansi keuangan ini meliputi: 1) penerimaan atau pemasukan, pemasukan keuangan pesantren dari berbagai sumber perlu dilakukan pembukuan berdasarkan prosedur yang disepakati, baik konsep teoritis maupun peraturan pemerintah. Sumbangan dana yang masuk ke pesantren bisa kita klasifikasi sebagai dana langsung dan dana tidak langsung. Dana tidak langsung adalah dana berupa perbandingan waktu guru dan peserta didik dalam menggunakan setiap waktunya di sekolah atau pesantren, seperti penyesuaian waktu belajar mengajar ketika dibandingkan dengan ketika guru atau peserta didik menggunakannya untuk bekerja, dan juga perhitungannya dengan transportasi, dan biaya hidup. Dana ini memang sulit sekali dihitung karena tidak ada catatan resminya. Namun dalam perencanaan biaya ini turut dihitung. Dana langsung, adalah dana yang di peroleh dari beberapa sumber 
yang sah; 2) pengeluaran, alokasi dari dana pendapatan pesantren harus pula diatur secermat mungkin.

Ada beberapa klasifikasi dalam pengeluaran dana yang di pakai secara umum di lembaga-lembaga pendidikan kita, yaitu: 1) dana pembangunan, pengeluaran dana ini diatur dan digunakan untuk pembangunan dan pembenahan sarana fisik lembaga, dana ini disesuaikan dengan kebutuhan dan jumlah guru serta peserta didik yang ada di lembaga pendidikan tersebut (Nanang Fatah, 2000; 26); 2) Dana rutin, dana rutin adalah dana yang digunakan untuk biaya operasional satu tahun anggaran. Dana rutin penggunaannya meliputi pelaksanaan program belajar mengajar, pembayaran gaji guru maupun personil, serta pemeliharaan dan perawatan sarana prasarana lembaga pendidikan.

Untuk menghitung dana rutin lembaga pendidikan harus menghitung total cost atau nilai unit cost yang dibutuhkan setiap siswa atau santri. Nilai unit cost merupakan nilai satuan biaya yang dikeluarkan untuk memberikan pelayanan terhadap seorang peserta didik setiap tahun dalam satu jenjang pendidikan. Berdasarkan akuntansi keuangan di pesantren, ada beberapa hal yang harus di perhatikan oleh bendaharawan pesantren: 1) membuat laporan keuangan kepada pesantren dan komite pesantren untuk dicocokkan dengan rancangan anggaran pesantren; 2) menyertakan bukti-bukti laporan keuangan, termasuk bukti pembayaran pajak bila ada; 3) kwitansi atau bukti-bukti pembelian dan penerimaan berupa tanda tangan penerima atau bukti pengeluaran yang lain; 4) menunjukkan neraca keuangan untuk diperiksa oleh tim penanggungjawaban keuangan dari yang bersangkutan. Hal-hal yang perlu dipersiapkan oleh bendaharawan pesantren meliputi: buku kas umum, buku persekot atau uang muka, daftar potongan-potongan, daftar honorarium, buku tabungan, buku iuran atau kontribusi santri, buku catatan untuk pengeluaranpengeluaran yang tidak terduga. (Sulthon Masyhud, t.t; 190).

\section{Simpulan}

Strategi rekonstruksi ekonomi pesantren adalah rencana yang disatukan, luas, dan terintegrasi yang menghubungkan keunggulan strategi pesantren dengan tantangan lingkungan dan yang dirancang untuk memastikan bahwa tujuan utama pesantren untuk sejahtera secara ekonomi dapat dicapai melalui pelaksanaan yang tepat oleh pesantren. Penulis menyimpulkan ada empat strategi rekonstruksi ekonomi pesantren, yaitu:

Strategi pertama adalah analisis potensi ekonomi pesantren. Potensi ekonomi yang dimiliki pesantren adalah: Pertama, kyai-ulama, kyai-ulama pesantren yang dipandang sebagai potensi pesantren yang mempunyai nilai ekonomis, setidaknya dapat kita lihat pada tiga hal: 1) kedalaman ilmu kyaiulama. 2) seorang kyai adalah tokoh panutan masyarakat dan pemerintah; 3) pada umumnya, seorang kyai sebelum membangun pesantren telah mandiri secara ekonomi; Kedua, santri, potensi ekonomi kedua yang melekat pada 
pesantren adalah para santri. Hal ini dipahami bahwa pada umumnya santri mempunyai potensi/bakat bawaan seperti kemampuan membaca Al-Qur'an, kaligrafi, pertukangan, dan lain sebagainya; Ketiga, pendidikan, potensi ekonomi dari pendidikan pesantren ini terletak pada santri/murid, guru, sarana dan prasarana. Dari sisi santri/murid, sudah barang tentu dikenai kewajiban membayar SPP, di samping sumbangan-sumbangan wajib lainnya.

Strategi kedua adalah implementasi prosedur anggaran. Kegiatan ini meliputi empat fase kegiatan pokok prosedur penganggaran keuangan, sebagai berikut: 1) perencanaan anggaran; 2) persiapan anggaran; 3) pengelolaan pelaksana anggaran, dan; 4) menilai pelaksanaan anggaran. Dalam penganggaran keuangan harus menerapkan prinsip anggaran berimbang, artinya antara pendapatan dan pengeluaran harus berimbang dan diupayakan tidak terjadi anggaran pendapatan minus.

Strategi ketiga adalah implementasi prinsip manajemen keuangan, antara lain adalah: Pertama, Prinsip Perencanaan; Kedua, Prinsip Pelaksanaan dan: Ketiga, Prinsip Pelaporan dan Pengawasan.

Strategi keempat adalah implementasi akuntabilitas dan transfaransi. Akuntabilitas adalah kondisi seseorang yang dinilai oleh orang lain karena kualitas performannya menyelesaikan tujuan yang menjadi tanggung jawabnya.

Akuntabilitas dalam mengembangkan dana pondok pesantren di mulai dari perencanaan, pengumpulan, pengelolaan, pemanfaatan, dan pertanggungjawaban. Langkah-langkah yang dilakukan pengelola pondok pesantren dalam melakukan akuntabilitas melalui tahapan-tahapan sebagai berikut: 1) Pra pelaksanaan akuntabilitas atau proses pengembangan dana pondok pesantren hal ini dilakukan dengan cara membentuk dua lembaga yaitu pertama Badan Usaha Milik Pesantren (BUMP) yang bertanggung jawab terhadap pengembangan dana pondok pesantren, kedua Badan Pengawas Keuangan Dan Kekayaan Ma'had (BPK2M) yang bertugas mengawasi kekayaan, aset dan keuangan pondok pesantren; 2) Pelaksanaan akuntabilitas dengan melalui pengurus harian dengan melakukan evaluasi setiap empat bulan sekali yang dipimpin langsung oleh pengasuh dan yang paling penting adalah; 3) merekrut pegawai akuntan yang profesional yang jujur. 


\section{DAFTAR PUSTAKA}

Anwar, Idochi, Administrasi Pendidikan Dan Manajemen Biaya Pendidikan; Teori, Konsep dan Isu, Bandung: Alfabeta, 2003.

Asmani, Jamal Ma'mur, Tips Aplikasi Manajemen Sekolah, Jogjakarta: DIVA Press, 2012.

Barnawi \& Arifin, M, Manajemen Sarana \& Prasarana Sekolah, Jogjakarta: Ar-Ruzz Media, 2012.

Bodnar, Goerge H dan Hopwood, William S, Sistem Informasi Akuntansi, Jakarta: Bumi Aksara, 2001.

Buang, Nor Aishah dan Murni, Isteti, Prinsip-Prinsip Kewirausahaan Konsep, Teori, Model Pembentukan Wirausaha, Bangi: Fakulti Pendidikan, Universiti Kebangsaan Malaysia, 2006.

Buford, Manajemen in Extention 2nd Edition, Alabama: Aubrn Universty.

Campbell, R. F., dan Nystrand, Introduction to Educational Administration, London: Allyn Press, 1983.

DEPAG RI, Pola Pengembangan Pondok Pesantren, Jakarta: DEPAG RI, 2000.

-------------, Pondok Pesantren dan Madrasah Diniyah Pertumbuhan dan Perkembangannya, Jakarta: DEPAG RI, 2003.

In Service Training KKM MTS/MI, Jakarta: PPIM, 2001.

Engkoswara, Paradigma Manajemen Pendidikan Menyongsong Otonomi Daerah, Bandung: Yayasan Amal Keluarga, 2001.

Fattah, Nanang, Landasan Manajemen Pendidikan, Bandung: PT. Remaja Rosdakarya, 2009.

-------------, Ekonomi dan Pembiayaan Pendidikan, Bandung: Remaja Rosda Karya, 2000.

George R. Terry, Principles of Management, Ontario: Richard D. Irwin. Inc, 1997. 
Haedari, Amin \& Elha, Ishom, Manajemen Mutu Terpadu Pesantren dan Madrasah, Jakarta: Diva Pustaka, 2004.

Halim, A, Menggali Potensi Ekonomi Pondok Pesantren, Yogyakarta: Pustaka Pesantren, 2005.

Halim, A, et. al. (eds), Manajemen Pesantren, Yogyakarta: Pustaka Pesantren, 2005.

Handoko, T. Hani, Manajemen Edisi 2, Yogyakarta: BPFE-UGM, 2011.

Hidayat, Ara dan Machali, Imam, Pengelolaan Pendidikan Konsep, Prinsip, dan Aplikasi dalam Mengelola Sekolah dan Madrasah, Bandung: Pustaka Educa, 2010.

Hikmat, Manajemen Pendidikan, Bandung: CV. Pustaka Setia, 2009.

Imron, Ali, at. al. (ed), Manajemen Pendidikan Analisis Substantif dan Aplikasinya dalam Institusi Pendidikan, Malang: Universitas Negeri Malang, 2003.

Longenecker, Justin G, dkk, Kewirausahaan: Manajemen Usaha Kecil, Buku 2, Jakarta: Salemba Empat, 2001.

Marzuki, Wahid, et al, Pesantren Masa Depan Wacana Pemberdayaan dan Transformasi Pesantren, Yogyakarta: Pustaka Hidayah, 2001.

Masyhud, M. Sulthon dan Khusnurdilo, M, Manajemen Pondok Pesantren, Jakarta: Diva Pustaka, 2003.

Massie, Joseph L, Dasar-dasar Manajemen, Jakarta, Erlangga, 1983.

Muhammad, Fadel, Reinventing Local Government Pengalaman dari Daerah, Jakarta: PT Elex Media Computindo, Compas Gramedia, 2008.

Mulyasa, E, Manajemen Berbasis Sekolah, Bandung: PT Remaja Rosdakarya, 2004.

Mulyono, Manajemen Administrasi dan Organisasi Pendidikan, Jogjakarta: Ar-Ruzz Media, 2010.

Munandar, Budgeting, Yogyakarta: BPE, 1997.

Nawawi, Hadari, Manajemen Strategik Organisasi Non Profit Bidang Pemerintahan dengan Ilustrasi dalam Bidang Pendidikan, Yogyakarta, Gadjah Mada Press, 2003. 
Partanto, Pius A dan al-Barry, M Dahlan, Kamus Ilmiah Populer, Surabaya: Arkola Surabaya, 1994.

Pidarta, Made, Perencanaan Pendidikan Partisipatori dengan Pendekatan Sistem, Jakarta: Rineka Cipta, 1990.

Poerwadarminta, W.J.S, Kamus Besar Bahasa Indonesia, Edisi. 2 Cetakan 4, Jakarta: Balai Pustaka, 1995.

Qardhawi, Yusuf, al Hill al Islami Faridhah Islamiah, Kairo: Bank al-Taqwa, TT.

Sagala, Syaiful, Manajemen Berbasis Sekolah dan Masyarakat, Jakarta: Nimas Multima, 2004.

Administrasi Pendidikan Kontemporer, Bandung: Alfabeta, 2005.

Suhardan, Dadang, Organisasi dan Manajemen Pendidikan Nasional. Dalam Pengantar Pengelolaan Pendidikan, Bandung: Tim Dosen Jurusan Administrasi Pendidikan UPI, 2001.

Sulistyorini, Manajemen Pendidikan Islam, Surabaya: eLKAF, 2006.

Diktat Manajemen Pendidikan Islam, Tulungagung: STAIN Tulungagung, 2004.

Sulthon, Manajemen Pondok Pesantren, Yogyakarta: Leksbang, 2006.

Syamsudduha, Manajemen Pesantren: Teori dan Praktek, Yogyakarta: Grha Guru, 2004.

Tim Penyusun IAIN Syarif Hidayatullah, Ensiklopedia.

Tim Penyusun, Pondok Pesantren dan Madrasah Diniyah Pertumbuhan dan Perkembangannya, Jakarta: Departemen Agama RI Direktorat Jenderal Kelembagaan Agama Islam, 2003.

Thoha, Habib, Kapita Selekta Pendidikan Islam, Yogyakarta: Pustaka Pelajar, 1996.

Umaedi, Panduan Manajemen Sekolah, Jakarta: Departemen Pendidikan Dan Kebudayaan, 1999.

Wahid, Marzuki, et al, Pesantren Masa Depan Wacana Pemberdayaan dan Transformasi Pesantren, Jakarta: Pustaka Hidayah, 2001. 
Ittihad Jurnal Kopertais Wilayah XI Kalimantan Volume 14 No.25 April 2016

Wahjoetomo, Perguruan Tinggi Pesantren Pendidikan Alternatif Masa Depan, Jakarta: Gema Insani Press, 1997.

Winardi, J, Entrepreneur, Jakarta: Kencana, 2004.

Zaini, Wahid, Pesantren Masa Depan, Bandung: Pustaka Hidayah 1999.

Zarkasyi, Abdullah Syukri, Manajemen Pesantren; Pengalaman Pondok Modern Gontor, Ponorogo; Trimurti Press, 2005. 